\title{
SCHOOL VIOLENCE: SUBJECTIVE THEORIES OF ACADEMIC ADVISORY BOARD MEMBERS FROM SIX CHILEAN SCHOOLS
}

\author{
Gabriella Natassia von Reininghaus*, Pablo Javier Castro** and \\ SUSANA FRISANCHO***
}

\author{
*MA in Psychology with an Educational Psychology mention. E-Mail: gabysalamanca10@hotmail.com \\ ${ }^{* *} \mathrm{PhD}$ in Psychology and Post-doctoral Fellow. Associate Professor in the Department of Psychology at \\ University of La Serena. Chile. \\ Departamento de Psicología, Universidad de La Serena, Avenida Matta, 147, Coquimbo, Chile. \\ E-Mail: pablocastro@userena.cl \\ ${ }^{* * * P h D}$ in Developmental Psychology. Principal Professor in the Department of Psychology at Pontifical \\ Catholic University of the Peru. Lima, Peru. E-Mail: sfrisan@pucp.edu.pe
}

\section{RESUMEN}

Se estudiaron las teorías subjetivas acerca de la violencia escolar de seis docentes directivos de seis establecimientos educacionales de la comuna de Coquimbo (Chile), tres de escuelas municipales (públicas) y tres de colegios particulares. El estudio fue de tipo cualitativo y la estrategia de recolección de datos utilizó una entrevista semiestructurada de aplicación individual, seguida por un instrumento de auto-reporte. Los resultados fueron analizados, organizados e interpretados en base a la teoría fundamentada, lo que permitió reconstruir las explicaciones que los directivos han construido acerca de la violencia escolar. Los resultados indican que todos los participantes conciben la violencia escolar como un problema social importante pero poco común en sus instituciones educativas. Además, asumen que la violencia se origina fundamentalmente por influencias externas que provienen de la sociedad en su conjunto, tales como el tipo de estructura familiar y los procesos de socialización en el hogar, la calidad de la educación recibida y la influencia de los medios de comunicación. Cuando piensan en variables del propio sujeto, usualmente atribuyen la violencia a una baja autoestima. En esta concepción, al dejar de lado la participación del in- dividuo como un agente racional que discierne y elabora juicios morales para guiar la acción, los directivos asumen una visión pasiva del sujeto como meramente respondiente a las influencias ambientales. Los hallazgos del estudio se discuten principalmente enfatizando sus implicaciones para la educación, específicamente para la educación moral y la prevención de la violencia.

Palabras clave: Docentes directivos; Teorías subjetivas; Violencia escolar; Dimensión moral; Estudio cualitativo.

\section{ABSTRACT}

This study analyzes the subjective theories regarding school violence held by six school officials of the city of Coquimbo (Chile). School violence is action carried out by a member of a school community that intends to cause harm against any member of that community. The study's main objective is to identify and interpret the various subjective theories regarding school violence held by the school officials as well as to explore whether there is a moral dimension to their subjective theories. We are interested in the moral dimension of the problem because research has 
shown that processes such as moral reasoning, moral identity, or moral motivation are linked to students' behavior in schools. Furthermore, social interactions are critical for the development of more advanced levels of moral reasoning. The study focuses on six members of the academic advisory board from six different schools, three municipal (public) schools and three subsidized private schools in the region of Coquimbo (Chile). Because the role of the administrative team is becoming increasingly important in the proper functioning of educational institutions, characteristics of school officials such as their leadership skills, negotiation skills, or abilities solve conflicts, have a direct impact on the success or failure of any educational program. Due to the qualitative approach of this study, each participant was interviewed using an individual semi-structured interview followed by a self-report questionnaire. Results were analyzed, organized, and interpreted based on grounded theory, which has been shown to be useful in analyzing subjective theories. Participants' explanations regarding school violence were reconstructed using the semantic categories that emerged in their interview responses. Results indicate that participants view school violence as an important social problem that should be contested; however, at the same time participants feel that it is not prevalent at their own educational institutions. Moreover, all participants believe that school violence takes place because of social influences, such as socialization processes at home, family values, quality of education, and influence of mass media, among others. This shows that participants hold a concept of the individual as merely respondent to environmental forces, lacking rational process and agency to discern and make moral judgments as a base for their actions. This is problematic because school violence has a moral dimension, as it involves issues of fairness, cooperation, conflict, negotiation with others, justice, and welfare. Results show that none of the participants understand violence as related to morality. Consequently, participants support traditional approaches to combat school violence aimed either at making students behave as it is prescribed by school norms or at enhancing students' social skills. However, such approaches disregard any moral education or moral discernment, even though research has identified moral values, the main variable in the study of social behaviour (Delfino \& Zubieta, 2011), and moral development as factors related to violence. In general, school officials regard violence as externally originated, caused mainly by social forces and cultural factors. They also have subjective theories that hold the causes of school violence to be external and unmanageable, minimizing their responsibility and their sense of efficacy in dealing with the problem. Assuming that a major role of education is to facilitate a better understanding of the world and knowing that teachers' beliefs are very important into explain teachers' behavior, the results of this study are discussed regarding its implications for education, particularly moral education and the prevention of violence.

Key words: Academic advisory board; Subjective theories; School violence; Moral dimension; Qualitative research.

\section{INTRODUCTION}

School violence is defined as actions carried out by a member of a school community that intend to cause harm against any member of that community, whether it be students, teachers, directors, staff, or parents. This type of violence arises within educational establishments but may also occur in other places associated with the school, such as nearby surroundings or places where extracurricular activities are conducted (Abramovay \& Rua, 2002; Díaz-Aguado, 2005; Mena \& Vizcarra, 2001).

School violence is currently regarded as something that alters the school environment and has negative consequences on students' well-being and learning (Mena \& Vizcarra, 2001). Several studies have shown that violence in schools generates physical and emotional damage, stress, lack of motivation, school absenteeism, and even negative school performance due to posttraumatic stress (Álvarez-García, Álvarez, Núñez, González-Castro, González-Pienda \& Rodríguez, 2010; Gumpel \& Meadan, 2000; Henao, 2006; Smith 
\& Thomas, 2000; Verlinde, Hersen \& Thomas, 2000). Unfortunately, in Chile and other Latin American countries teachers and students perceive school violence as a normal part of a school's daily life and as a means to gain power and status (Figueroa, Marambio, Miranda, Salazar, \& Zamora, 2005; Loza \& Frisancho, 2010). Studies have shown that teachers create subjective theories that hold the causes of violence to be external and unmanageable. In this way, they view the causes as either external to the school or genetical / biological and, therefore, unchangeable (Cuadra, 2009; López, Carrasco, Morales, Ayala, López \& Karmy, 2011; Loza \& Frisancho, 2010; Volante \& Müller, 2006). It has also been shown to be quite common for all levels of school staff to underestimate the number of students involved in violent actions (Bradshaw, Sawyer, \& O'Brennan, 2007).

Although it is important to acknowledge that the definition of school violence varies culturally and historically, it is also true that it exists in many different countries and with varying prevalence rates. It affects both developing and industrialized countries, and it is linked to social exclusion and inequalities (Akiba, Letendre, Baker \& Goesling, 2002; Debarbieux, 2003; Mateo, Ferrer, \& Mesas, 2009; Ohsako, 2001). In Chile, a number of studies already identify school violence as a problem (see Tijmes, 2012 for a summary of recent studies on this topic). Due to the pervasiveness of the problem in Chile and throughout the world, there is an urgent need within educational communities not only to efficiently intervene in situations with a violent outcome but also to prevent them altogether (Arón \& Milicic, 1999; Bausela, 2008; Orte Socías \& Ballester Brage, 2007). In fact, school violence is gaining momentum as a social problem and, thus, is becoming a worrisome issue. This is not only a contentious issue for researchers but also for school officials who are now beginning to adopt diverse intervention measures in order to attenuate a situation that is complex and difficult to both define and to manage effectively (Ortega, Del Rey, \& Mora-Merchán, 2001).
Frequently, traditional approaches to combat school violence are aimed at establishing self-control within students in order to make them behave as it is prescribed by school rules and norms. Too often, such interventions have regarded violence as a problem related mainly to the violation of school or social conventions, thus, reducing violence to a disobedience of the rules or norms of a particular social group. The underpinning idea is that school violence is a problem primarily caused by a poor environment or by lack of control over the behavior of the students. Additionally, it is sometimes held that the student who perpetrates the aggression has psychopathic traits, is emotionally disturbed, and will show a pattern of anti-social behaviour in the future (Bender \& Lösel, 2011; Renda, Vassallo, \& Edwards, 2011; Sutton, Smith, \& Swettenham, 2010; Sourander et al., 2007). Following this, it is not surprising that many think that violence

"can be curtailed with more stringent gun laws, surveillance cameras, armed policeman patrolling the halls, and metal detectors" (Edwards, 2001, p. 249).

It appears that school officials in several places favor legal remedies such us having metal detectors inside schools, punishing the aggressor, or passing laws (Time \& Payne, 2008). Similarly, in Chile and other South American countries many think that such violence can be reduced by the implementation of a law (Law $\mathrm{N}^{\circ} 20.536$ "Anti-bullying Law in the Case of Chile"). In any case, such strategies are punitive, focusing only on the aggressor and, therefore, lack a holistic approach oriented at developing students' capabilities of understanding human relationships from an ethical perspective.

All this ignores any approach to moral education and moral discernment, which is problematic because, although not often recognized, school violence has a moral dimension (Edwards, 2001; Horton, 2011; Jacobson, 2010). Violence involves causing harm and producing suffering to another person while violating his or her rights as a 
human being. It also encompasses either asymmetrical power relationships or abuse of power within relationships. According to Turiel (1983), morality can be understood as notions of justice and welfare, right or wrong, which are acknowledged by most societies. In this sense morality stands apart from the social or conventional rules that maintain most social interactions. Rather, morality is embedded in actions that pertain to the recognition of human rights as well as the welfare and fair treatment of individuals. The growing interest in school violence is precisely related to the increasing public awareness of the fundamental rights people are entitled to (Avila, 2005). It is important to note that psychological research has already identified moral reasoning as an important factor in school violence (see Manning \& Bear, 2011 for a review of studies on this topic). Similarly, other moral processes such as moral motivation, moral identity, or moral disengagement have also been related to school violence (Gasser \& Keller 2009; Paciello, Fida, Tramontano, Lupinetti, \& Caprara, 2008; Wainryb, Komolova, \& Florsheim, 2010). Additionally, Delors identifies moral values as essential for education, declaring that

"it is no exaggeration on the Commission's part to say that the survival of humanity depends thereon" (1996, p. 16).

In this vein, understanding the moral dimension of school violence will allow teachers and school administrators to implement programs that contribute to the reduction of school violence. Such programs aim to improve moral reasoning capacities, to foster the abilities for role taking, to enhance the development of a moral point of view in order to relate to others, and to encourage the development of ethical and caring students. Although it is acknowledged that school violence is a complex phenomenon that should be confronted at different levels (school, classroom, individual, and community), its moral dimension is an important factor commonly neglected (Espelage \& Swearer, 2010; Olweus \& Limber, 2010).

\section{THE ROLE OF SCHOOL OFFICIALS}

The ways in which schools are managed affects all its activities and so, the role of the principal and the administrative team is becoming increasingly important in the proper functioning of educational institutions. In Chile schools are managed by a principal and an academic advisory board of teachers. These teachers do not have an assigned classroom themselves but work with the principal as part of a technical-administrative team, making decisions to improve educational processes and helping other teachers to improve their practices. They are very common in the Chilean educational system, and they usually hold a master degree or have special training in areas such as curriculum studies or counselling. We refer to members of these academic boards as school officials.

The leadership capabilities and performance of school officials have a direct impact on the success or failure of any educational program (Concha, 2007; Mena, Becerra, \& Castro, 2011). Through their actions, teachers and school officials can either encourage competitiveness or conflict among students or can facilitate cooperation and understanding (García \& Valerio, 2005; Ortega, 2000; Trianes, 2000). Ultimately, they have the power to create a positive or negative school environment that strongly impacts the socio-emotional development, behavior, and learning of students (Valdés et al., 2008; Resnick et al., 1997; Wang, Haertel, \& Walberg, 1993). This is especially relevant since the Chilean education system bears certain characteristics that may sharpen school violence, mainly due to the heterogeneity of Chilean students (Guerra, Alvarez-Gabría, Dobarro, Núñez, Castro, \& Vargas, 2011). It is believed that heterogeneity

"can lead to poor academic performance and greater incidences of not getting along, particularly in disadvantaged schools" (Guerra et al., 2011, p. 77. Own translation).

Some authors have proposed that school officials should establish non-violence stan- 
dards within schools while at the same time developing positive interpersonal relationships between students and staff (Antúnez, 1999; Díaz-Aguado, 2005; Kadel \& Follman, 1993). Measures such as monitoring hallways, visiting classrooms, strengthening school programs and policies, and being accessible to students and staff provide a means through which school officials can reduce the incidence of violent behaviour (Kadel \& Follman, 1993). However, in addition to those very relevant functions, from a moral perspective school officials should also be moral and democratic leaders with the goal of enhancing democratic and moral values and developing autonomy and humanity in educational practices. In order to achieve this, their beliefs about the connection between morality and school violence, their concepts of moral and democratic education, and their conviction that it is their responsibility to enhance the moral development of students are all very important (Joseph \& Efron, 2005).

\section{SUBJECTIVE THEORIES}

The concept of subjective theories is attributed to Groeben and Scheele (1977, in Groeben \& Scheele, 2001) and is defined as complex cognition aggregates of the research object, in which their cognitions relating to the self and the world become manifest and which show an at least implicit argumentational structure.

Subjective theories (STs) are personal theories constructed in order to explain a perceived reality and have a cause-effect argumentative structure. Although these personal theories are social in nature, it does not detract from the value of individual representations (Castro, 2012; Catalán, 2010; Flick, 2009). Flick (2009) views STs as day to day hypotheses that people generate about themselves and their surroundings in order to relate to others.

It has been shown that subjective theories greatly influence understanding and course of action taken by professionals (Flick, 2009). This is in large part because they serve as powerful tools in the explanation and inter- pretation of an individual's reality and have a notable impact on their actions (Avendaño, Krause, \& Winkler, 1993; Moncada, 2005; Flick, 1991, cited by Krause et al., 2006). A recent literature review on professional knowledge of teachers (Catalán, 2011; Porlán, Rivero, \& Martín, 1998) suggests the importance of the use of subjective theories as a tool in the study of educators' thought processes.

Because performance and beliefs of school officials regarding school violence have not been sufficiently explored in Chile, the present study is aimed at answering this question: How do school officials explain and interpret school violence as it occurs at educational establishments? The main objective of this study is to interpret and understand the various subjective theories regarding school violence held by a group of school officials in the city of Coquimbo. We aimed to identify how school officials perceive school violence and whether they integrate the moral dimension into their subjective theories of the phenomenon.

\section{METHOD}

This research was based on an interpretive paradigm, focused on the description and understanding of individual behaviours: their beliefs, intentions and drives (Goetz \& Le Compte, 1984; Guba, 1990; Krause, 1995).

The present study is descriptive-interpretative in nature, with the objective of obtaining detailed descriptions to further interpret the context in order to obtain data (Goetz \& Le Compte, 1984; Valles, 1999).

\section{PARTICIPANTS}

Individual semi-structured interviews were conducted with six school officials, male and female, all of whom were members of the academic advisory board of the City of Coquimbo, IV Region.

The educational institutions were chosen in accordance with the variation sampling strategy (Flick, 2009); they included three public (municipal) schools, in which most students 
belong to the low to medium social class, and three subsidized private schools, in which students belong to the middle to upper social class. For the purpose of this study, we were interested in the perspective of the academic advisory board on school violence. Based on the availability of each member for the completion of the interview and self-report questionnaire, the final sample consisted of three principals (one female, two male), one female counselor, one female general inspector, and one male head of the technical-pedagogical unit.

\section{Procedure AND COLLECTION OF DATA}

All interviews were conducted at the institutions' facilities and were recorded with previous consent for better accuracy. The interview explored the school officials' subjective theories about the following topics: the origins of violence, effects of school violence, perception of violence at their schools, and the role teachers have in the prevention of violence.

Interviews were followed by a self-report questionnaire so that school officials could describe in writing the views given in the interview and for subsequent triangulation of data (Denzin, 1989). This questionnaire was based on the Questionnaire to Teachers previously used by Mena (2001) and described in Halcartegaray (2006). It explores school teachers' perceptions of coexistence problems in the school. Teachers were asked to recall a specific situation of school violence that they had experienced at their schools, noting it on a piece of paper. They were to reflect upon the experience, analyzing the decisions they made in that situation and the logic supporting those decisions.

\section{DATA ANALYSIS}

Content analysis was based on data provided by the participants through the questionnaires and the six interviews. Data obtained was analyzed using grounded theory (Glaser \& Strauss, 1967), as it has been shown to be useful in analyzing subjective theories. Grounded theory offers a qualitative research tool that accounts for meaning and life experiences of the subjects (Strauss \& Corbin, 2008). It is a research method that allows for the inductive creation of a theory based on a corpus of data; data is gathered and analyzed, and the theory is derived from that data through a process of codification and interpretation (Flick, 2009).

The analysis was made following the standard procedures of Grounded Theory, particularly its three codification systems: open coding (identifying, naming, categorizing, and describing phenomena found in the interviews and the self-report questionnaire), axial coding (relating the previously coded categories to each other using inductive and deductive thinking), and selective coding (the process of drawing up a narrative report integrating the categories of axial coding) (Glasser \& Strauss, 1967; Strauss \& Corbin, 2008). Axial coding of grounded theory was applied to identify school officials' STs on the categories that emerged from the interview discourse: School violence, Society, Mass media, Education, Ideal education, and Family. From the data obtained in the axial coding and through the use of selective coding, a general comprehensive model was built to reconstruct each school official's subjective theory regarding school violence (see Figure 1).

\section{RESULTS}

CONTENT ANALYSIS OF SUBJECTIVE THEORIES ${ }^{1}$

According to the interviewees, the world today is a violent place, as is Chilean society

\footnotetext{
Subjective theories: $\mathrm{TP}=$ subsidized private school; $\mathrm{TM}=$ public school.

Supra indexes: $1=$ subjective theory of subsidized private school officials on the interview; $2=$ subjective theory of public school officials on the interview; 3 = subjective theory of public school officials on the questionnaire; 4 = subjective theory of subsidized private school officials on the questionnaire.

Numbers name every subjective theory that originates a category.
} 
$\left(\mathrm{TP}^{1} 18^{1}\right)$. They believe violence to be everywhere: within the family, on the streets, and in the schools; in turn, this has contributed to the increase in school violence. One of the interviewees explains:

"The world is a very violent place nowadays. It is a social problem. There are problems with families that affect school life. There are problems with television too, and unfortunately children live surrounded by all that. They are being taught how to do bad things. They know that if a 14 years old kid hits another child nothing happens; they watch TV and see all that. Then they say "so, since you did it and nothing happened, I can do it as well" (school official, subsidized private school. Own translation).

Officials believe that the concept of family has radically changed in the last few decades. According to officials, families are becoming increasingly "unstructured" $\left(\mathrm{TM} \mathrm{c}^{3} 4\right)$, "single-parent" ( $\left.\mathrm{TM}^{2} 52\right)$, or "pseudo families" (T $\left.\mathrm{P}^{1} 26\right)$ with both parents working outside the home; this leaves children alone for extended periods of time ( $\left.\mathrm{T} \mathrm{M}^{2} 12,40,42,51\right)$ and allows them "freedom in excess and lack of boundaries" (TP' 22, 23. Own translation).

Officials believe that parents allow their children to watch too much uncensored television $\left(\mathrm{T} \mathrm{M}^{2} 13,43\right.$; $\left.\mathrm{T} \mathrm{P}^{1} 32, \mathrm{~T} \mathrm{P} \mathrm{c}^{4} 2\right)$ or play violent games on the computer $\left(\mathrm{TM}^{2} 13,43\right)$, which is problematic because "children copy those violent patterns seen in the media" (TP ${ }^{1}$ $1,17,33,49, \mathrm{TM}^{2} 44, \mathrm{TP} \mathrm{c}^{4} 2$, own translation). They also think that there is a "lack of government support for families" ( $\mathrm{TP}^{2} 35$, own translation) and that parents have become more aggressive, both at school $\left(\mathrm{TM}^{2} 16 \mathrm{~T} \mathrm{M}^{1}\right.$ 5 ) and at home, mainly due to alcohol abuse $\left(\mathrm{TP}^{1} 10\right)$. For instance, they say:

"Society as a whole is the problem, but the nucleus, let's say it this way, is the family. But right now the concept of family in Chile has changed. The traditional family is no longer alive; the classic concept has died. So our children...they are not well educated at home. They do not get any moral education at home, any respect for principles. And the family, this pseudofamily, you know, wants us in the school to take care of the problem" (school official, subsidized private school. Own translation).

"In Chile we have lost the concept of family. Mom and dad have to work, and when they are at home, they are very tired. So, they just turn on the TV, get a movie for the children or a computer game, and that's it. This is the way they spend the day; they do not share quality time with their children anymore. And again during the weekend parents just play movies for the kids, so they themselves can take a rest. This way we are losing old values... old values that were very good" (school official, public school. Own translation).

School officials also stress the role of families in educating their children, because they believe that it is poor family education that leads to violence in the school (TP 12$)$. According to the principal of a subsidized private school, it is not the role of the school "to educate / educar"2 children but to encourage academic performance, as measured through the PSU and SIMCE (Chilean standardized tests) ( $\mathrm{T} \mathrm{P}^{1} 28,24$ y 27$)$.

Furthermore, as previously mentioned, school officials think that the media plays an important role in school violence; this is because it promotes the type of aggression between kids and their peers known as cyber bullying $\left(\mathrm{TP}^{1} 36,47\right)$, and since "children use the media as a means to commit violent behaviour" (TP' 47$)$. Although officials seem to be doubtful regarding their responsibility on

2 In Spanish the word educar is more comprehensive than the English verb "to educate" in the sense that the former not only refers to class instruction but also to moral and values education (Halgunseth, Ispa, \& Rudy, 2006). 
cyber bullying ( $\left.\mathrm{TP}^{1} 37\right)$, they seem to definitively know it is affecting students, making it more imperative for them to intervene.

"The problem in this school is only with internet, Facebook. Kids are calling each other names through Facebook, and every now and then some kid responds to it. We also had one kid that use to hit everybody else. His mom said it was because he was glued to the computer, too many computer games, played some sort of transformer game, and he tried to imitate all that here in the school. But there is nothing more than that. There is no maltreatment here" (school official, subsidized private school. Own translation).

"I believe we are not to blame. We have to blame the system, I insist, because once a year we should have a psychological and psychiatric evaluation, so a specialist can say to us: look, you can keep working, go ahead; or: you failed the test in this and that, go to therapy if you want to improve. The government is not interested in our spiritual processes, our mental processes. We work with very difficult and demanding children, and no one prepares us; we may not be fully prepared for this task" (school official, public school. Own translation).

As we can see, even though they recognize violence as a social problem and are aware that it appears at their schools through social networking services, such as Facebook, school officials seem to minimize the incidence of school violence and even perceive their own institutions as free from it. This is clearly seen in the following statement:

"Here we do not have violence. Children here may be as violent as any other, but they do not express it inside the school. They do not fight in the school, never. In the past we had this problem, sure, but not anymore. Now we have better kids, more good kids than bad kids; we have improved" (school official, public school. Own translation).
According to school officials, over the years there has been a change in the way teachers are viewed as authority figures. Previously, students demonstrated respect towards teachers; as explained by an official, "we were gods and children were nothing, now we are equals" $\left(\mathrm{TM}^{2} 38\right.$. Own translation). Nowadays students do not show such respect for their teachers, and there is a loss in teachers' identities when facing student issues. As a result, school officials feel it vital to have a "multidisciplinary team" in place $\left(\mathrm{TM}^{2} 10\right)$, more innovative teachers $\left(\mathrm{TP}^{1} 15,16\right)\left(\mathrm{TP}^{1}\right.$ 4 ), and a more efficiently organized school that is able to develop a

\section{“...systematization of strategies" (T M ${ }^{2} 5$. Own translation).}

The perceived lack of public policy and programs against school violence at national $\left(\mathrm{TM}^{2} 27\right)$ and federal levels has greatly impacted the problem $\left(\mathrm{TP}^{1} 8,25,19,26,39\right.$ TM $^{2}$ $4,27)$. Participants complained about schools having to develop their own strategies to face violent occurrences; they also expressed the need for

"a set of standard procedures on school violence implemented by the State" $\left(\mathrm{TM}^{2} 4\right.$. Own translation).

Finally, it is important to point out that in addition to identifying the social processes as causes of school violence, school officials also mention its relation to internal psychological processes such as self-esteem. The following paragraph provides a good example of this idea:

"We are working very hard on our students' social skills and self-esteem. They have very low self-esteem, and this does not allow them to be kind people, nice people, because they do not love themselves. On the contrary, they hate themselves, and all this rage turns towards others" (school official, public school. Own translation). 


\section{CONCLUSIONS AND DISCUSSION}

The main purpose of this study was to identify the subjective theories regarding school violence held by six school officials of the city of Coquimbo. We also investigated whether their subjective theories included a moral dimension.

Educational management is paramount to school coexistence. In our complex world, schools should enhance learning and development and foster the psychological well-being of its members, preparing students for the challenges of everyday life. Moreover, schools are important places to foster ethical principles, citizenship education, and moral discernment, all of which are fundamental processes for the development of individuals and for the construction of a better and fair society. In this sense, as institutions of progress and development, schools should be safe places; managing school coexistence not only comprises administering the school but also managing personnel with an approach that takes into account social, emotional, and ethical aspects of education. Within this train of thought emerges a very important question: Do school officials integrate the moral dimension into their subjective theories about school violence?

According to the school officials that participated in this study, school violence is a reality and will continue to increase due to interrelated factors. Such factors include living in a violent society, having unstructured family settings, being exposed to uncensored mass media, and having an educational system which does not offer standards or strategies to deal with violence. Interestingly Chile does sponsor public programs focused on preventing school violence, such as the Ministry of Education's National Program for School Coexistence or the Skills for Life Program (JUNAEB,1998), among others. However school officials participating in this study insist that there is a lack of government support as well as a lack of set standards on school violence. Further research is needed to understand the origins of this perception and to determine whether such public programs are effective.
It is interesting to see that even though all participants believe that school violence is prevalent and problematic in Chilean society, they think it does not occur in their own institutions. When the existence of school violence is acknowledged, they characterize it as fairly low, predominately verbal, and occurring mostly through the internet. Because studies have shown that bullying and other types of violence are common in many schools throughout the world (Mateo et al, 2009; Smith, Morita, Junger-Tas, Olweus, Catalano, \& Slee, 1999; Oros, 2008), it seems that these school officials do not accurately perceive or purposely minimize school violence. In general, school officials regard violence as externally originated, caused mainly by social forces and cultural factors. Because officials believe that school violence is not the direct responsibility of the school members but of society and the mass media, the intervention strategies they mentioned were not directed at preventing or solving problems within the school. In fact, most officials reported both lack of violence in their schools and external sources for violence, thus, perceiving prevention efforts as being out of their reach.

Participants also reported that in the case that violent behaviour does occur at school, they will immediately communicate it to parents, recommending psychological support for the involved students. This shows the underpinning notion that aggressors are students who have personal or internal difficulties that will improve with psychotherapy or other individualized intervention. These difficulties are most likely a pervasive pattern of disregard for and violation of the rights of others, lack social skills, poor emotional and cognitive development, low self-esteem, or limitations with affective responses or with their ability to truly empathize with others. However, as results show, none of the participants understood violence as related to morality, ethical thinking, role taking, a caring perspective in behaving toward others, or moral education. As we have tried to make clear in this paper, this is an important dimension of the problem that needs to be taken into account in order to deal with it effectively. As such, en- 
hancing psychological processes, such as awareness of our own cognitive distortions, moral capabilities, and role-taking abilities, should be a fundamental part of any educational program.

Sadly, in this study school officials did not mention any educational strategy or pedagogical intervention that included a social justice point of view or a moral standpoint, nor did they identify moral development or moral reasoning as related to violent behavior. This is worrisome since students, based on an ethical and human rights framework and their moral reasoning, can choose not to hurt others and, rather, to behave in such a way that enhances the rights and well-being of everyone. Unfortunately, the results of this study indicate that school officials maintain a prevalent belief about human nature in general and school violence in particular that is twofold: either it is caused by social forces and cultural processes (the main explanation participants gave), or it has a biological origin. In this picture, there is no room for thought, reasoning, discernment, choice, and human agency. As Turiel (2010) points out, it is as if irrationality were the main characteristic of human nature; determinism -either environmental or biological- being the strongest explanation. Nevertheless, because human life inevitably entails conflict, people are always confronted with moral decisions. They must decide which courses of action to take and need to devel- oped capacities to back these decisions with moral principles and from a moral point of view. We see that the lack of connection between morality and school violence shown by school officials will limit the kind of pedagogical interactions they will have with both teachers and students.

A limitation of the study may be the use of a self-report to triangulate data, since it seemed that officials based the information reported on the information they had given in the semistructured interview. However, this may also be interpreted as officials having consistent STs, since there was no significant difference between statements given in the interviews and statements gathered through self-report. Therefore, we believe that this investigation contributes to creating awareness in regards to Chilean school officials' beliefs about school violence. It allows us to see that there is no moral dimension present in the subjective theories of the participants. For this reason, it may be important to incorporate a moral dimension into teachers' training programs, allowing both teachers and school administrators to become aware of its importance. Finally, as the sample size of the present study is a shortcoming and limits the possibility that the results of this research may be generalized to the rest of the population, it is important to not only increase the sample size in future investigation, but also to incorporate other educational actors such as teachers and principals. 

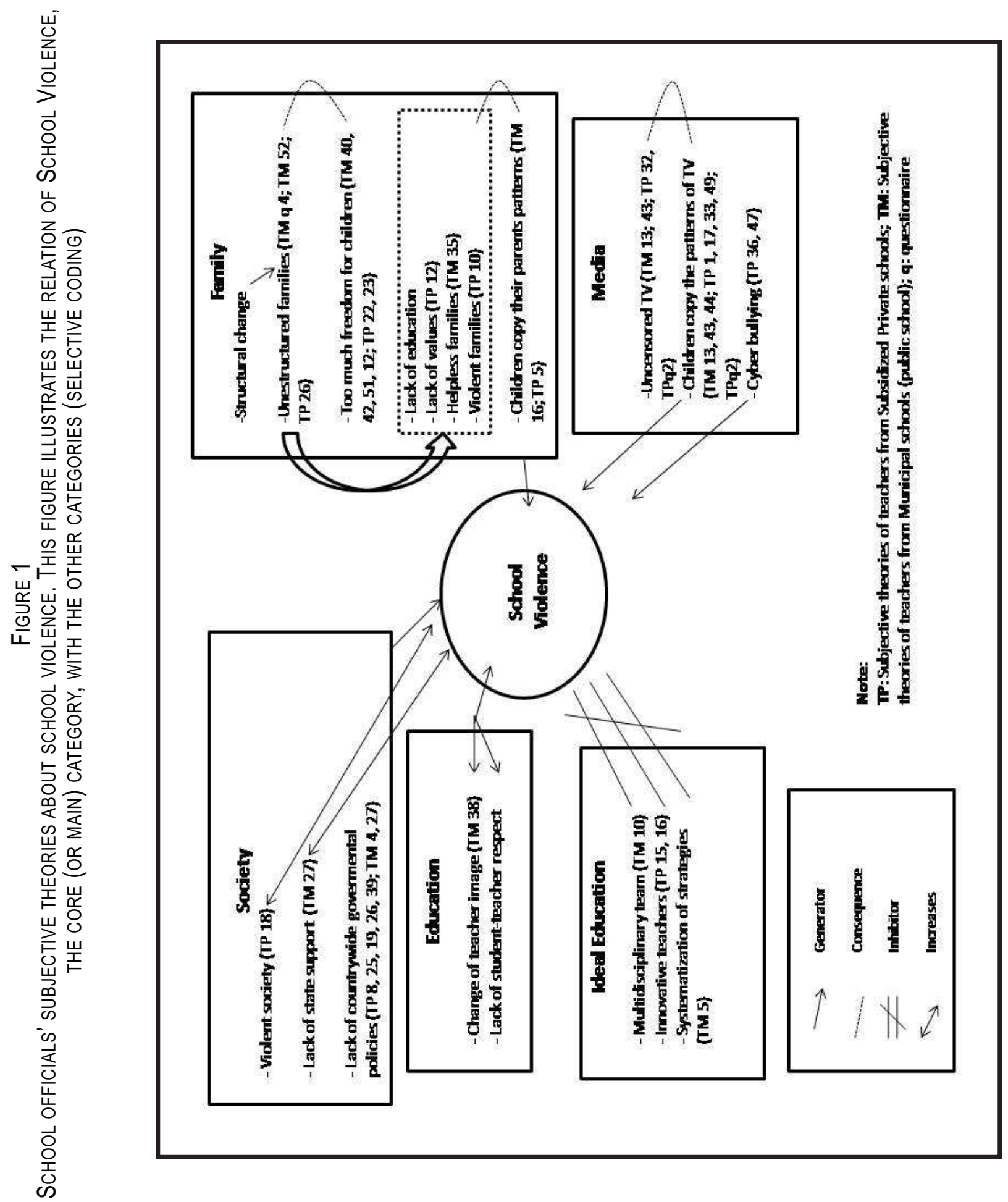


\section{REFERENCES}

Álvarez-García, D., Álvarez, L., Núñez J.C., González-Castro, P., González-Pienda, J., \& Rodríguez, C. (2010). Violencia en los centros educativos y fracaso académico [Violence in schools and academic failure]. Revista Iberoamericana de Psicología y Salud, 1, 130153.

Abramovay, M. \& Rua, M. (2002). Violences in the schools. Brasília: UNESCO, Coordenação DST/AIDS do Ministério da Saúde, Secretaria de Estado dos Direitos Humanos do Ministério da Justiça, $\mathrm{CNPq}$, Instituto Ayrton Senna, UNAIDS, Banco Mundial, USAID, Fundação Ford, CONSED, UNDIME.

Akiba, M., Letendre, G.K., Baker, D.P., \& Goesling, B. (2002). Student victimization: National and school system effects on school violence in 37 nations. American Educational Research Journal, 39(4), 829-853.

Antúnez, S. (1999). El trabajo en equipo de los profesores y profesoras: Factor de calidad, necesidad y problema. El papel de los directivos escolares [The teamwork of the teachers: Quality factor, need and problem. The role of school leaders]. Revista Educar, 24, 35-39.

Arón, A. \& Milicic, N. (1999). Climas sociales tóxicos y climas sociales nutritivos para el desarrollo personal en el contexto escolar [Toxic and nutritive social school climates and personal development in school contexts]. Psykhe, 2, 117-123.

Avila, F. (2005). Derechos humanos y cultura en el siglo XXI. [Human rights and culture in the twenty-first century]. Cadernos PROLAM/ USP, 4(2), 77-101.

Bender, D. \& Lösel, F. (2011). Bullying at school as a predictor of delinquency, violence and other anti-social behaviour in adulthood. Criminal Behaviour and Mental Health. Special Issue: Criminal Consequences of School Bullying, 21(2), 99-106.

Bradshaw, C.P., Sawyer, A.L., \& O'Brennan, L.M. (2007). Bullying and peer victimization at school: Perceptual differences between stu- dents and school staff. School Psychology Review, 36(3), 361-382.

Bausela, E. (2008). Estrategias para prevenir el bullying en las aulas [Strategies to prevent bullying in classrooms]. Intervención Psicosocial, 17, 369-370.

Battistich, V., Solomon, D., Kim, D., Watson, M., $\&$ Schaps, E. (1995). Schools as communities, poverty levels of student populations, and students' attitudes, motives and performance: A multilevel analysis. American Educational Research Journal, 32(3), 627-658.

Castro, P.J. (2012). Cambio de teorías subjetivas de profesores: Respecto a la enseñanza y el aprendizaje de valores [Change of teachers' subjective theories: About teaching and learning values]. Saarbrücken: EAE.

Catalán, J. (2010). Teorías subjetivas, aspectos teóricos y prácticos [Subjective theories, theoretical and practical aspects]. La Serena: Editorial Universidad La Serena.

Catalán, J. (2011). Del pensamiento al conocimiento profesional del profesor [From thinking to teachers' professional knowledge]. In J. Catalán (Ed.), Psicología educacional: Proponiendo rumbos, problemáticas y aportaciones (pp. 187-215). La Serena, Chile: Editorial Universidad de La Serena.

Chile. Biblioteca del Congreso Nacional (2011). Ley Número 20.536 sobre violencia escolar [Law No. 20,536 about school violence]. Retrieved January 21, 2013 from http://www. ley chile.cl/Navegar? idNorma $=1030087$

Concha, C. (2007). Claves para la formación de directivos de instituciones escolares [Keys to the training of managers of educational institutions]. Revista Iberoamericana sobre Calidad, Eficacia y Cambio en la Educación, 5 (5e), 133-138. Retrieved November 13, 2012 , from http://www.rinace.net/arts/vol5num5e/ art18.htm

Cuadra, D. (2009). Teorías subjetivas en docentes de una escuela de bajo rendimiento, sobre la enseñanza y el aprendizaje del alumno [Teachers' subjective theories in an low achievement school, about teaching and student learning]. 
Revista Mexicana de Investigación Educativa, 14(42), 939-967.

Delfino, G.I. \& Zubieta, E.M. (2011). Valores y política: Análisis del perfil axiológico de los estudiantes universitarios de la ciudad de Buenos Aires (República Argentina) [Values and politic. Axiological profile analysis of college students in the city of Buenos Aires (Argentina)]. Interdisciplinaria, 28(1), 93-114.

Delors, J. (1996). Learning: The treasure within. Report to UNESCO of the International Commission on Education for the Twenty-first Century. Retrieved December 12, 2012 from http://unesdoc.unesco.org/images/0010/001 0 95/109590eo.pdf

Debarbieux, E. (2003). School violence and globalisation. Journal of Educational Administration, 41(6), 582-602.

Denzin, N. (1989). The research act. Englewood Cliffs: Prentice Hall.

Díaz-Aguado, M.J. (2005). Por qué se produce la violencia escolar y cómo prevenirla [Why school violence occurs and how to prevent it]. Revista Iberoamericana de Educación, 37, 1747.

Edwards, C. (2001). Student violence and the moral dimensions of education. Psychology in the Schools, 38(3), 249-257.

Espelage, D.L. \& Swearer, S.M. (2010). A socialecological model for bullying prevention and intervention: Understanding the impact of adults on the social ecology of youngsters. In S.R. Jimenson, S.S. Swearer \& D.L. Espelage (Eds.), Handbook of bullying in schools: An international perspective (pp. 61-86). Nueva York: Routledge.

Figueroa, Y., Marambio, L., Miranda, C., Salazar, M. \& Zamora, A. (2005). Representaciones sociales sobre la violencia escolar en liceos vulnerables. Un estudio cualitativo exploratorio [Social representations of school violence in vulnerable schools. An exploratory qualitative study]. Santiago, Chile: Universidad Academia de Humanismo Cristiano.

Flick, U. (2009). An introduction to qualitative research (4th ed.). London: Sage.
García, R. \& Valerio, E. (2005). La violencia escolar, miradas de los agentes educativos. Un análisis de sus representaciones sociales [School violence, points of view of educators. An analysis of their social representations]. X Congreso Nacional de Investigación Educativa. Área 17 Convivencia, disciplina y violencia en las escuelas. Retrieved January 21, 2013, from http:/www.comie.org.mx/congre so/memoriaelectronica/v10/pdf/area tematica_17/ponencias/1535-F.pdf

Gasser, L. \& Keller, M. (2009). Are the competent the morally good? Perspective taking and moral motivation of children involved in bullying. Social Development, 18(4), 798-816.

Glaser, B. \& Strauss, V. (1967). The discovery of the grounded theory. Chicago: Aldine.

Goetz, J. \& LeCompte, M. (1984). Ethnography and qualitative design in educational research. New York: Academic Press.

Groeben, N. \& Scheele, B. (2001). Dialoguehermeneutic method and the "Research Program Subjective Theories". Forum Qualitative Social Research, 2(1), Art. 10, Retrieved January 21, 2013 from http://www.qualitativeresearch.net/index.php/fqs/article/vie w/1079/2353

Guba, E. (1990). The paradigm dialog. London, England: Sage.

Guerra, C., Alvarez-Gabría. D., Dobarro, A., Núñez, J.C., Castro, L. \& Vargas, J. (2011). Violencia escolar en estudiantes de educación secundaria de Valparaíso (Chile): Comparación con una muestra española [School violence in high school students from Valparaiso (Chile): Comparison with a Spanish sample]. Revista Iberoamericana de Psicología y Salud, 2(1), 75-98.

Gumpel, T. \& Meadan, H. (2000). Children's perceptions of school-based violence. British Journal of Educational Psychology, 70, 391404.

Halcartegaray, M. (2006). Construcción de problemas de convivencia escolar por parte de profesores de enseñanza básica y media [Construction of school coexistence problems by 
primary and secondary school teachers]. Tesis doctoral no publicada. Universidad de Chile, Facultad de Ciencias Sociales, Chile. Retrieved April 12, 2013 from http://www.cybertes is.cl/tesis/uchile/2006/halcartegaray_m/html/i ndex-frames.html

Halgunseth, L.C., Ispa, J.M., \& Rudy, D. (2006). Parental control in latino families: An integrated review of the literature. Child Development, 77(5), 1282-1297.

Henao, J. (2006). La prevención temprana de la violencia: Una revisión de programas y modalidades de intervención [Early prevention of violence: A review of programs and methods of intervention]. Universitas Psychologica, 4(2), 161-177.

Horton, P. (2011). School bullying and social and moral orders. Children \& Society, 25(4), 268277.

Jacobson, R. (2010). On bullshit and bullying: taking seriously those we educate. Journal of Moral Education, 39(4), 437-448.

Joseph, P. \& Efron, S. (2005). Seven worlds of moral education. Phi Delta Kappan, 86(7), 525-533.

JUNAEB (1998). Programa Habilidades para la Vida [Skills for Life Program]. Retrieved January 31, 2013 from http://www.junaeb.cl/pron tus junaeb/site/artic/20100112/pags/20100112 114344.html 31.01.13

Kadel, S. \& Follman, J. (1993). Reducing school violence in Florida. Hot topics: Usable research. Washington, DC: South Eastern Regional Vision for Education. Office of Educational Research and Improvement.

Krause, M. (1995). La investigación cualitativa: Un campo de posibilidades y desafíos [Qualitative research: A field of possibilities and challenges]. Revista Temas de Educación, 7, 1-22.

Krause, M., de la Parra, G., Arístegui, R., Dagnino, P., Tomicic, A., Valdés, N. (...), \& Ramírez, R. (2006). Indicadores genéricos de cambio en el proceso psicoterapéutico [Indicators of change in the psychotherapeutic process]. Revista Latinoamericana de Psicología, 3, 325-329.
López, V., Carrasco, C., Morales, M., Ayala, A., López, J., \& Karmy, M. (2011). Individualizando la violencia escolar: Análisis de prácticas discursivas en una escuela municipal de la Región de Valparaíso [Individualizing school violence: Analysis of discursive practices in a public school in the Region of Valparaíso]. Psykhe, 20(2), 7-23. http://dx.doi.org/10.406 7/S0718-22282011000200002

Loza, J. \& Frisancho, S. (2010). ¿Por qué pegan los niños? Creencias sobre la agresividad infantil en un grupo de profesoras de educación inicial [Why do children hit others? Kindergarten teachers' beliefs about aggressive behavior in children]. Revista Peruana de Investigación Educativa, 1(2), 59-86. Retrieved January 8, 2013 from http://siep.org.pe/archi vos/up/159.pdf

Manning, M. \& Bear, G.G. (2011). Moral reasoning and aggressive behavior: Concurrent and longitudinal relations. Journal of School Violence, 10(3), 258-280.

Mateo, V.F., Ferrer, M.S., \& Mesas, C.G. (2009). Un estudio descriptivo sobre el acoso y violencia escolar en la educación obligatoria [Descriptive study about school bullying and violence in obligatory education]. Escritos de Psicología, 2(2), 43-51.

Mena, M.I. (2001). Metodología para el trabajo en valores en el marco de los objetivos transversales de la reforma educativa [Methodology for values education in the context of cross-curricula objectives of educational reform]. (Proyecto FONDEF 2001/D01I1040). Santiago. Escuela de Psicología de la Pontificia Universidad Católica de Chile y Programa Interdisciplinario de Investigaciones en Educación.

Mena, I., Becerra, S., \& Castro, P. (2011). Gestión de la convivencia escolar en Chile: Problemáticas, anhelos y desafíos [Management of school life in Chile: Problems, aspirations and challenges]. In J. Catalán (Ed.), Psicología educacional proponiendo rumbos, problemáticas y aportaciones (pp. 81-112). La Serena, Chile: Editorial Universidad de La Serena. 
Mena, I. \& Vizcarra, R. (2001). Algo nuevo bajo el sol: Hacer visible el maltrato y posible la esperanza [Something new under the sun: Making abuse visible and hope possible]. Psykhe, 10, 81-101.

Moncada, L. (2005). Teorías subjetivas del cambio terapéutico desde la perspectiva de los terapeutas [Subjective theories of therapeutic change from the perspective of therapists]. Tesis doctoral no publicada. Facultad de Ciencias Sociales, Universidad de Chile. Chile.

Olweus, D. \& Limber, S. (2010). Bullying in school: Evaluation and dissemination of the Olweus Bullying Prevention Program. American Journal of Orthopsychiatry, 80(1), 124134.

Oros, L.B. (2008). Promoviendo la serenidad infantil en el contexto escolar: Experiencias preliminares en una zona de riesgo ambiental [Promoting child serenity at school: Preliminary experiences in an area of environmental risk]. Interdisciplinaria, 25(2), 181-195.

Ortega, R. (2000). Educar la convivencia para prevenir la violencia [Educating school coexistence to prevent violence]. Madrid: Antonio Machado Libros.

Ortega, R., Del Rey, R., \& Mora-Merchán, J. (2001). Conceptos y etiquetas verbales que definen el fenómeno del maltrato entre iguales [Concepts and verbal labels that define the phenomenon of bullying]. Revista Interuniversitaria de Formación del Profesorado, 41, 95-113.

Orte Socías, C. \& Ballester Brage, L. (2007). Prevención del comportamiento delictivo en la comunidad [The prevention of the criminal behavior in the community]. Intervención Psicosocial, 16, 269-281.

Ohsako T. (2001) Violence at school: Global issues and interventions. Paris: UNESCO.

Paciello, M., Fida, R., Tramontano, C., Lupinetti, C., \& Caprara, G.V. (2008). Stability and change of moral disengagement and its impact on aggression and violence in late adolescence. Child Development, 79(5), 1288-1309. http: //dx.doi.org/10.1111/j.1467-8624.2008.0118 9. $\mathrm{x}$
Porlán, R., Rivero, A., \& Martín, R. (1998). Conocimiento profesional y epistemología de los profesores, II: Estudios empíricos y conclusiones [Professional knowledge and epistemology of teachers, II: Empirical studies and conclusions]. Enseñanza de las Ciencias, 16 (2), 271-288.

Renda, J., Vassallo, S. \& Edwards, B. (2011). Bullying in early adolescence and its association with anti-social behaviour, criminality and violence 6 and 10 years later. Criminal Behaviour and Mental Health. Special Issue: Criminal Consequences of School Bullying, 21(2), 117-127.

Resnick, M.D., Bearman, P.S., Blum, R.W., Bauman, K.E., Harris, K.M., Jones, J., (...), \& Udry, J.R. (1997). Protecting adolescents from harm. Findings from the national longitudinal study on adolescent health. JAMA, 278 (10), 823-832. http://dx.doi.org/10.1001/jam a.1997.03550100049038

Serrano, A. \& Iborra, I. (2005). Violencia entre compañeros en la escuela [Peer violence at school]. Madrid: Goaprint.

Smith, P.K. (2000). Bullying and harassment in schools and the rights of children. Children \& Society, 14(4), 249-303.

Smith, H. \& Thomas, S. (2000). Violent and nonviolent girls: Contrasting perceptions of anger experiences, school, and relationships. Issues in Mental Health Nursing, 21(5), 547-575.

Smith, P.K., Morita, Y., Junger-Tas, J., Olweus, D., Catalano, R., \& Slee, P. (Eds.). (1999). The nature of school bullying. New York: Routledge.

Sourander, A., Jensen, P., Rönning, J.A., Niemelä, S., Helenius, H., Sillanmäki, L. (...), \& Almqvist, F. (2007). What is the early adulthood outcome of boys who bully or are bullied in childhood? The Finnish "From a Boy to a Man" study. Pediatrics, 120(2), 397404. http://dx.doi.org/10.1542/peds.2006-2704

Strauss, A. \& Corbin, J. (2008). Pesquisa qualitativa: Técnica e procedimentos para o desenvolvimento da teoria fundamentada [Basics of qualitative research: Techniques and procedu- 
res for developing Grounded Theory]. Porto Alegre: Artmed.

Sutton, J., Smith, P.K. \& Swettenham, J. (2010). Social cognition and bullying: Social inadequacy or skilled manipulation? British Journal of Developmental Psychology, 17(3), 435450.

Tijmes, C. (2012). Violencia y clima escolar en establecimientos educacionales en contextos de alta vulnerabilidad social de Santiago de Chile [School violence and school climate in schools of Santiago, Chile, in high vulnerable social contexts]. Psykhe, 21(2), 105-117.

Time, V. \& Payne, B.K. (2008). School violence prevention measures: School officials' attitudes about various strategies. Journal of Criminal Justice, 36(4), 301-306.

Trianes, M.V. (2000). La violencia en contextos escolares [Violence in school contexts]. Málaga: Aljibe.

Turiel, E. (2010). Snap judgment? Not so fast: Thought, reasoning, and choice as psychological realities. Human Development, 53, 105109.

Turiel, E. (1983). The development of social knowledge: morality and convention. Cambridge: Cambridge University Press.

Valdés, H. (Coord.), Treviño, E., Acevedo, C., Castro, M., Carrillo, S., Costilla, R., Bogoya, D., \& Pardo, C. (2008). Los aprendizajes de los estudiantes de América Latina y el Caribe. Primer reporte de los resultados del segundo estudio regional comparativo y explicativo [The learning of students in Latin America and the Caribbean. First report of the results of the second regional comparative and explanatory research]. Santiago de Chile: UNESCO-OREA LC.

Valles, M. (1999). Técnicas cualitativas de investigación social: Reflexión metodológica y práctica profesional [Qualitative techniques of social research: Methodological reflection and professional practice]. Madrid: Editorial Síntesis.

Verlinde, S., Hersen, M., \& Thomas, J. (2000). Risk factors in school shootings. Clinical Psychology Review, 20, 3-56.

Volante, P. \& Müller, M. (2006). Cambios en el discurso sobre resultados de aprendizajes en escuelas de bajo rendimiento y alta vulnerabilidad social [Changes in the discourse about learning results obtained by low achievement and high social vulnerability schools]. Revista Pensamiento Educativo, 39(2), 205-224.

Wainryb, C., Komolova, M., \& Florsheim, P. (2010). How violent youth offenders and typically developing adolescents construct moral agency in narratives about doing harm. In K. McLean \& M. Pasupathi (Eds.), Narrative development in adolescence: Creating the storied self (pp. 185-206). New York: Springer.

Wang, M.C., Haertel, G.D., \& Walberg, H.J. (1993). Toward a knowledge base for school learning. Review of Educational Research, 63(3), 249-294.

Reception: February 5, 2013

Accepted: October 18, 2013 